\title{
Physicochemical Properties and Sensory Evaluation of Wheat-Purple Rice Biscuits Enriched with Green-Lipped Mussel Powder (Perna canaliculus) and Spices
}

\author{
Warinporn Klunklin (D) and Geoffrey Savage \\ Department of Wine, Food and Molecular Biosciences, Faculty of Agriculture and Life Sciences, Lincoln University, Lincoln 7647, \\ Christchurch, New Zealand
}

Correspondence should be addressed to Warinporn Klunklin; warinporn.klunklin@lincolnuni.ac.nz

Received 13 December 2017; Revised 5 March 2018; Accepted 25 March 2018; Published 8 May 2018

Academic Editor: Ángel A. Carbonell-Barrachina

Copyright (c) 2018 Warinporn Klunklin and Geoffrey Savage. This is an open access article distributed under the Creative Commons Attribution License, which permits unrestricted use, distribution, and reproduction in any medium, provided the original work is properly cited.

\begin{abstract}
Biscuits are one of the most consumed bakery products eaten by everyone. Purple rice contains much higher levels of antioxidants, vitamins, and minerals such as iron and zinc compared to wheat. The aim of this work was to produce a protein-rich biscuit made from purple rice flour and defatted green-lipped mussel powder (Perna canaliculus) (0-20\%) blended with ginger and galangal spices at $4 \%$ for each spice. The objective was to produce an inexpensive, balanced, healthy snack product containing increased levels of protein and antioxidants from the mussel powder and to investigate the consumer preferences of these biscuits using the four different ethnic groups (Thai, Chinese, Caucasian, and Pacific Islanders) living in New Zealand. The addition of the mussel powder increased the crude protein content by $43 \%$ and the protein digestibility by $21 \%$ at the highest level of inclusion. The addition of mussel powder significantly $(p<0.05)$ increased the hardness of biscuits while making small increases in the browning index of the cooked biscuit. The phenolic contents and antioxidant activities (DPPH and ABTS) were significantly $(p<0.05)$ increased as additional amounts of mussel powder were incorporated into the biscuit mix, resulting in a reduction in the total starch contents. The addition of $10 \%$ mussel powder to the control biscuit mix was accepted by all the ethnic groups. Overall, the Pacific Islanders showed a higher appreciation for all the attributes tested.
\end{abstract}

\section{Introduction}

Biscuits are a ubiquitous snack food that many people are unable to resist eating because they are readily available, are bite-sized, are affordable, and have a long shelf-life. As a result, biscuits are highly favored bakery items [1]. They cannot, however, be regarded as a healthy snack food because they usually contain high levels of easily digested carbohydrates and fats, generally low levels of fiber, and only modest levels of protein as they are usually made from flour, butter, and sugar [2]. Recent trends suggest that people are aware of the food they consume and they are also aware of benefits of consuming nutritious biscuits [3].

The development of a high-protein-containing biscuit is a worthwhile challenge when considering the overall nutritional status of underprivileged sections of the population.
In considering the development of a new product, it is important to use locally sourced ingredients and spices whose tastes are appreciated by each ethnic group the products are intended for [3]. Commercial green-lipped mussels (Perna canaliculus) are popular as raw materials and dietary supplements because they contain high protein levels, omega-3 fatty acids, iodine, and carbohydrates [4]. In addition, mussels contain proteins, peptides, and amino acids which are bioactive compounds. These have different bioactivities such as antimicrobial mussel peptides or anti-inflammatory, antiarthritic, and anticancer agents $[4,5]$. There has been little research on the use of mussel powders in food products. The manufacture of glutenfree pasta mixed with different levels of green-lipped mussel powder has been studied by Vijaykrishnaraj et al. [6] and later by Vijaykrishnaraj et al. [7] who made gluten-free bread enriched with different levels of green mussel protein hydrolysates. 
Defatted green-lipped mussel powder is a by-product following the extraction of most of the oil fraction. It still contains some fat, but much less than that in the original powder. However, the addition of mussel powder to various food products has a number of problems associated with the processing and shelf-life of the final products [8].

Researchers have recently become interested in functional foods containing antioxidants due to the health-promoting activities of these compounds [9]. Antioxidants are mostly used to preserve food products by extending their shelf-life [1]. Purple rice (Oryza sativa L.) is reported to contain higher levels of antioxidants than white rice [10]. Purple rice is an economically important rice species, so it is preferred for the preparation of snacks and desserts. In addition, it has many nutritional benefits as it contains more protein, vitamins, and minerals than white rice [10].

Spices have been used in Asian cooking for thousands of years. Traditionally, spices, such as ginger, garlic, clove, and turmeric, were added to foods to reduce the level of microorganisms, but it is now becoming clear that these spices also have important antioxidant properties and can slow down color degradation in cooked products. Spices can extend the shelf-life by slowing lipid oxidation [11]. Ginger (Zingiber officinale Roscoe) and its derivatives contain major pungent and active compounds and have a high antioxidant activity (DPPH assay) [12]. Galangal (Alpinia galanga), a member of the ginger family, is an aromatic spice that is widely used in Southeast Asia [11]. One of the most interesting properties of galangal is its effect on lipid oxidation in fish muscle systems [13]. The benefits from biscuits on human health depend on their ingredients [14]. In spite of the benefits from spices, the impact on health of people consuming high amounts of wheatpurple rice flour mixed with mussel powder remains unstudied and requires clarification.

The aim of this study was to investigate formulations for a series of biscuits using novel ingredients, including purple rice flour, mussel powder, and spices (ginger and galangal). The aim was to produce a balanced, low-cost, and healthy snack product. Considering the potential health benefits of purple rice and mussel powder and the increasing consumption of healthy food, the objective of the present study was to prepare nutritious biscuits to deliver a nutritious and healthy product. It is important, however, to understand the response of different ethnic groups to this new product.

\section{Materials and Methods}

2.1. Raw Materials. The ingredients used were plain wheat flour (Pams Products Ltd., NZ), purple rice distributed by the Big T Supermarket in New Zealand, butter (Dairyworks, NZ), caster sugar (Pams Products Ltd., NZ), baking powder (Edmonds Limited, NZ), salt (Pams Products Ltd., NZ), whole egg (Pams Products Ltd., NZ), vanilla extract (Pams Products Ltd., NZ), xanthan gum (Lotus foods Pty Ltd., Australia), honey (Airborne Honey Limited, NZ), ginger (Zingiber officinale) and galangal (Alpinia galanga) powders, imported by Sunson gifts and the Asian food market, and defatted green-lipped mussel powder (Perna canaliculus) (containing $61.50 \%$ protein, $16.70 \%$ carbohydrate, $8.89 \%$ fat,
TABle 1: Formulation of control and fortified biscuits.

\begin{tabular}{lcc}
\hline \multirow{2}{*}{ Ingredients } & \multicolumn{2}{c}{ Experimental biscuits $(\mathrm{g})$} \\
& Control & Fortified biscuit \\
\hline Wheat flour & 100 & 100 \\
Purple rice flour & 100 & 100 \\
Defatted mussel powder & - & Varied from \\
Butter & 150 & $10 \%$ to $20 \%$ \\
Sugar & 125 & 150 \\
Egg & 225 & 125 \\
Salt & 1.5 & 225 \\
Galangal & - & 1.5 \\
Ginger & - & 8 \\
Sodium bicarbonate & 9 & 8 \\
Xanthan gum & 2.5 & 9 \\
\hline
\end{tabular}

and $8.46 \%$ ash) provided by Aroma New Zealand Limited, Christchurch, NZ. The experimental biscuits were prepared by the addition of defatted green-lipped mussel powder at levels of $0 \%, 10 \%, 15 \%$, and $20 \%$ of the total flour weight.

2.2. Preparation of the Biscuits. The control biscuits were made from a 50:50 blend of wheat flour and purple rice flour milled using the Whisper Mill (Grote Molen Inc., USA). The ingredients are shown in Table 1. Mussel powder was blended with mixed flour at $0-20 \%$ based on the dry weight of the flour. The biscuit dough was rolled out to a thickness of $10 \mathrm{~mm}$, using a rolling pin, and then cut into rounds using a $5 \mathrm{~cm}$ diameter biscuit cutter. The cut biscuits were baked at $170^{\circ} \mathrm{C}$ for $8 \mathrm{~min}$ and cooled at room temperature for $20 \mathrm{~min}$. The biscuits were stored in sealed plastic bags at $-20^{\circ} \mathrm{C}$ until further analysis could commence. Physical analysis was carried out on the freshly baked biscuits, while chemical analysis was carried out on the ground samples.

2.3. Proximate Analysis. Proximate analysis, including crude protein $(\% N \times 6.25)$ using the Dumas method by rapid Max N exceed ${ }^{\circledR}$ (Elementar, Hanau, Germany), crude fat, and ash, was determined using the AOAC methods 920.177, 920.176, and 900.029, respectively [15]. The moisture content was determined using a drying oven at $105^{\circ} \mathrm{C}$ for $18 \mathrm{~h}$. The total starch content was determined using the Megazyme starch assay kit (Megazyme International Ireland Ltd., Wicklow, Ireland) approved method 76-13 [16]. Total dietary fiber (TDF) was determined using a total dietary fiber assay kit (Sigma-Aldrich, MO, USA). All proximate composition measurements were conducted in triplicate.

2.4. In Vitro Protein Digestibility. In vitro protein digestibility of the biscuits was assessed according to the method of Akeson and Stahmann [17]. The protein digestion method used a twostep hydrolysis to stimulate continuous gastric and pancreatic digestion in humans using pepsin from the porcine gastric mucosa (Sigma Aldrich, USA; 66 units/mg protein) and pancreatin from a porcine pancreas (AppliChem Chemica Synthesis, Germany; 30.315 units/mg protein). The solutions were then centrifuged at $1600 \times \mathrm{g}$ for $10 \mathrm{~min}$. The supernatants 
were collected to analyze for total nitrogen using an Elementar (Hanau, Germany) Vario TOC cube instrument fitted with a chemiluminescence detector for determining total bound nitrogen $(\mathrm{TNb})$. The crude protein contents were calculated $(\% N \times 6.25)$. The analyses were performed in triplicate.

2.5. In Vitro Starch Digestibility. The digestion involved a simulated gastric digestion followed by a small intestine digestion using the method from Monro et al. [18]. Briefly, a $10 \%$ pepsin (porcine, Sigma, P 7000; 800-2,500 U/mL) solution in $0.05 \mathrm{M} \mathrm{HCl}$ was added to the sample solutions to digest for $30 \mathrm{~min}$ to accomplish gastric digestion. Starch digestion was then commenced with the addition of $5 \mathrm{~mL}$ of 2.5\% pancreatin (EC: 232-468-9; activity: $30315 \mathrm{FIP}-\mathrm{U} / \mathrm{g}$; AppliChem GmbH, Darmstadt, Germany) in $0.1 \mathrm{M}$ sodium maleate buffer ( $\mathrm{pH}$ 6). Triplicate samples were taken for each time interval $(0,20,60$, and $120 \mathrm{~min})$ after adding the pancreatin solution. The digested samples were then centrifuged at $180 \times \mathrm{g}$ for $5 \mathrm{~min}$. The absorbance of the supernatant was read at $530 \mathrm{~nm}(\mathrm{~V}-1200$ spectrophotometer; Global Science, Auckland, New Zealand).

2.6. Physical Characteristics. The textural properties of the biscuits were measured using a texture analyzer (TA-XT2i; Stable Micro Systems, Godalming, UK) equipped with a $30 \mathrm{~kg}$ load cell. The hardness of the freshly baked biscuits was measured by the cutting force, using a small three-point bending test rig with a sharp-blade cutting probe [2]. The first peak force was recorded as the hardness force in N. All measurements were repeated six times.

Biscuit quality was assessed by measuring the width, thickness, and biscuit spread ratio (width/thickness) (AACC method 10-50.05) [19]. This method is also useful in assessing the quality of the flour and other ingredients that can affect the biscuit shape (AACC method 10-50D) [19, 20]. All measurements were repeated six times.

The Minolta Chroma Meter CR-410 (Konica Minolta, Japan) was used to measure the color of the rice flour samples. The color was expressed using the $L^{*} a^{*} b^{*}$ CIE system [21]. According to Ruangchakpet and Sajjaanantakul [22], the browning index was calculated using the following equation:

$$
\text { Browning index }=\frac{100(x-0.31)}{0.17},
$$

where $x$ is $\left(a^{*}+1.75 L^{*}\right) /\left(5.645 L^{*}+a^{*}-0.3012 b^{*}\right)$. All measurements were repeated six times.

\subsection{Extraction and Determination of the Samples for Anti-} oxidant Analysis. Sample extraction was performed using a method adapted from Jang and Xu [23]. One gram of each sample was transferred into a test tube before adding $10 \mathrm{~mL}$ methanol acidified with $1.2 \mathrm{M} \mathrm{HCl}(50: 50, \mathrm{v} / \mathrm{v})$ and then vortexed for $30 \mathrm{~s}$. The tubes were capped and placed in a water bath at $60^{\circ} \mathrm{C}$ for $1.5 \mathrm{~h}$. The test tubes were mixed by vortexing twice during the incubation and then centrifuged at $4500 \times \mathrm{g}$ for $10 \mathrm{~min}$. The extracts were kept at $-20^{\circ} \mathrm{C}$ until further analysis could commence. The total phenolic content was analyzed by a Folin-Ciocalteu assay adapted from Kaneda et al. [24]. The method of Zhishen et al. [25] was used to analyze total flavonoid contents. The anthocyanin content analysis was determined using the method of Hosseinian et al. [26]. The determinations were carried out in triplicate.

2.8. Antioxidant Activities (DPPH and ABTS Assays). The DPPH (2,2-diphenyl-2-picrylhydrazyl) radical scavenging activity of the samples was tested according to the method of Mahakunakorn et al. [27]. The ABTS [2,2'-azinobis-(3ethylbenzothiazoline-6-sulfonic acid)] radical cation scavenging activity was performed using Re et al.'s method [28]. All determinations were conducted in triplicate.

2.9. Sensory Analysis. Students and staff members from the university campus were invited to participate in the full taste test. The sensory evaluation protocol was approved by the Lincoln University Human Ethics Committee (2017-24). Consumer focus groups used people from the four ethnic groups: Thai, Chinese, Caucasian, and Pacific Islanders. There were between 36 and 37 semitrained people in each ethnic group (in total, there were 60 males and 85 females ranging from 19 to 50 years).

The participants were asked to use a seven-point hedonic scale to rate their degree of liking $(1=$ dislike extremely; $4=$ neither like nor dislike; and $7=$ like extremely) [29]. The samples were presented at room temperature in clear plastic cups labeled with three-digit random numbers. The order of the presentation of the samples was randomized. The samples were served one day after baking.

2.10. Statistical Analysis. The data collected from all experimental sections were statistically analyzed by one- or two-way ANOVA using a complete randomized design and using a randomized complete block design for sensory evaluation. The data means were analyzed using Duncan's multiple range test for a multicomparison of means. A bivariate correlation matrix of data was analyzed using Pearson's correlation coefficient. The statistical significance was declared at $p<0.05$. Each of the experimental sections was carried out in triplicate. All statistical analyses were carried out by using the SPSS Statistics (v. 22.0; SPSS Inc., Chicago, IL, USA). The least significant differences (LSDs) were calculated to compare the means at the $95 \%$ level $(p<0.05)$ using Minitab (v. 17; Minitab Inc., State College, PA, USA).

\section{Results and Discussion}

3.1. Basic Composition of the Biscuits. Table 2 shows the proximate composition of the fortified biscuits containing different amounts of mussel powder. The enriched biscuits contained increased qualities of protein and total dietary fiber (TDF) when compared to the control biscuits. The moisture contents of the biscuits ranged from 5.3-6.5\%; 10\% 
TABle 2: Proximate analysis, protein digestibility, and AUC of digested starch of the fortified biscuits prepared from wheat-purple rice flour blends mixed with mussel powder and spices ${ }^{\mathrm{e}}$.

\begin{tabular}{|c|c|c|c|c|c|c|c|c|}
\hline & $\begin{array}{c}\text { Moisture } \\
\text { content (\%) }\end{array}$ & $\begin{array}{c}\text { Crude } \\
\text { protein }(\%) \\
\end{array}$ & $\begin{array}{c}\text { Protein } \\
\text { digestibility (\%) }\end{array}$ & $\begin{array}{l}\text { Total } \\
\text { fat }(\%)\end{array}$ & Ash (\%) & $\begin{array}{c}\text { Total } \\
\text { starch (\%) }\end{array}$ & $\begin{array}{c}\text { AUC }^{\mathrm{f}} \text { of digested } \\
\text { starch }(\mathrm{mg} \mathrm{min} / \mathrm{dL})\end{array}$ & $\begin{array}{c}\text { Total dietary } \\
\text { fiber (\%) }\end{array}$ \\
\hline Con & $5.30 \pm 0.1^{\mathrm{b}}$ & $7.91 \pm 0.02^{d}$ & $69.1 \pm 0.9^{c}$ & $20.68 \pm 0.16^{b}$ & $2.51 \pm$ & $31.28 \pm 0.25^{\mathrm{a}}$ & $588.1 \pm 2.1^{\mathrm{a}}$ & $12.96 \pm 0.18^{\mathrm{d}}$ \\
\hline $\begin{array}{l}\text { Mussel } \\
\text { powder } 10 \%\end{array}$ & 5.79 & $932+00$ & ? & $5^{\mathrm{a}}$ & & $9^{\mathrm{b}}$ & 54 & \\
\hline $\begin{array}{l}\text { Mussel } \\
\text { powder 15\% }\end{array}$ & 5.70 & $10.22=$ & $6^{\mathrm{a}}$ & 22.20 & & 26.08 & 507.2 & 25.85 \\
\hline $\begin{array}{l}\text { Mussel } \\
\text { powder 20\% }\end{array}$ & $6.50 \pm 0.1^{\mathrm{a}}$ & $11.29 \pm 0.09^{\mathrm{a}}$ & $83.5 \pm 0$. & $22.43 \pm 0.05^{\mathrm{a}}$ & $3.31 \pm 0.01^{\mathrm{a}}$ & $27.52 \pm 0.30^{\mathrm{b}}$ & $488.2 \pm 1.6^{\mathrm{d}}$ & $28.59 \pm 0.31^{\mathrm{a}}$ \\
\hline $\mathrm{LSD}^{\mathrm{g}}$ & 0.5 & 0.11 & 2.3 & 0.25 & 0.08 & 1.55 & 3.2 & 1.90 \\
\hline
\end{tabular}

${ }^{\mathrm{e}}$ Different superscripts (a, b, c, and d) in each column represent the significant difference (Duncan's multiple range test, $p<0.05$ ); values represent mean \pm standard error. ${ }^{\mathrm{f}}$ Area under the curve (AUC) of digested starch can predict glycemic response of each biscuit. ${ }^{\mathrm{g}} \mathrm{LSD}$, least significant difference.

is suggested as the upper limit needed for the biscuits to prevent spoilage by microorganisms and to increase the shelf-life [30]. The moisture contents of all biscuits were below this level. The water released from the biscuit matrix was altered by the mussel powder and spice supplementations due to their higher contents of saccharides in fortified biscuits than the control biscuits. Increasing the fiber contents resulted in higher water absorption capacities of the fortified biscuits [31]. Therefore, the final moisture content of the $20 \%$ mussel powder biscuit had a significantly higher moisture content compared to the other biscuits. The acceptable moisture content in freshly baked biscuits is normally less than 5\% [31]; however, the acceptance of the experimental biscuits was tested by different ethnic groups using a taste test.

The fortified biscuit with $20 \%$ mussel powder had the highest crude protein (11.29\%) content compared to the control (7.9\%). The green-lipped mussel powder has a quantity of protein content around $49.5 \%$ [6, 32]. Normally, biscuits have low protein content, in the region of $4.0 \%$ [33]. Sozer et al. [21] reported that wheat flour contains gluten protein, which contains approximately $14 \%$ protein. Moreover, Kaneda et al. [24] stated that protein contents of purple rice flour ranged between 9 and 13\%, and this depends on the cultivars evaluated. Such an increase comes from the fact that wheat-purple rice flour that was used for baking as a control also contains some protein contents. Furthermore, the incorporation of mussel powder increased the protein content of these products to more than that found in most commercial products [6].

The biscuits enriched with mussel powder contained significantly higher amounts of digestible protein $(80.9 \%)$ in comparison to the control sample (69.1\%). The data obtained by Abdel-Aal [34] and Vitali et al. [14] showed that in vitro protein digestibility of wheat-based biscuits ranged from $44.3 \%$ to $68.9 \%$, which was lower than that in this study. Vitali et al. [14] stated that the baking process did not cause any rise in protein digestibility since there was no significant difference in the available protein between the dough and biscuit samples. In contrast, Sumczynski et al. [35] reported that the baking process could increase the protein digestibility by inactivating proteinase inhibitors. Lima et al. [36] stated that pigmented rice such as purple rice has contributed to increased protein digestibility (75.33\%). In addition, ginger and galangal have been recognized as functional ingredients, which can improve digestive capacity [11]. Biscuits containing mussel powder showed a direct increase in protein digestibility following increased additions of mussel powder. Nørgaard et al. [37] confirmed that the addition of mussel protein in the diet of pigs increased the overall digestibility of protein in the diet.

The fortified mussel powder biscuits showed significantly $(p<0.05)$ higher fat and ash contents than the control biscuits. Short-dough biscuits commonly sold in shops normally contain high fat contents in the excess of $20.0 \%$ [33]. Vijaykrishnaraj et al. [6] reported that green-lipped mussel powder contained $2.7 \%$ ash. Ginger and galangal also contain $2.6 \%$ ash. The addition of mussel powder and spices in the biscuits increased the ash content compared to the control biscuits. Following the incorporation of mussel powder, total starch content of the mussel powder biscuits significantly decreased $(p<0.05)$ compared to the control biscuits.

Biscuit products primarily consist of starch from wheatpurple rice flour and some mussel polysaccharides; therefore, the determination of functionality of the starch is very important to understand. The predicted glycemic response of each biscuit can be measured by determining the area under the curve (AUC) for the digested starch at $2 \mathrm{~h}$ (Table 2). The AUC of the control biscuit gave the highest response, while the biscuit enriched with 20\% mussel powder gave the lowest value. An obvious reduction in the AUC of the fortified biscuits compared to the control indicated the lower release of carbohydrates in the enhanced mussel powder biscuits. The lower digestibility of biscuits incorporated with increasing levels of mussel powder together with the inclusion of spices might be attributed to their higher dietary fiber (DF) and resistant starch contents because the DF can reduce the digestibility of starch granules [38]. Moreover, polyphenols have been shown to be inhibitors of $\alpha$-amylase as they reduced both the activity of the digestive enzymes and the in vitro starch digestibility [39].

The total dietary fiber (TDF) content of various varieties of purple rice and wheat varies between 3.0 and $15.5 \%$ and 2.0 and $14.0 \%$, respectively [40]. Ginger and galangal also contain up to $11 \% \mathrm{TDF}$. Therefore, protein contents from wheat, purple rice, and spices are responsible for the increased 
TABle 3: Physical characteristics of fortified biscuits with different levels of mussel powder ${ }^{\mathrm{e}}$.

\begin{tabular}{|c|c|c|c|c|c|c|c|c|}
\hline & \multirow[b]{2}{*}{ Hardness $(N)$} & \multicolumn{3}{|c|}{ Biscuit quality } & \multicolumn{3}{|c|}{$L^{*} a^{*} b^{*}$ surface color } & \multirow{2}{*}{$\begin{array}{l}\text { Browning } \\
\text { index }{ }^{\mathrm{g}}\end{array}$} \\
\hline & & $\begin{array}{c}\text { Width } \\
(W, \mathrm{~mm})\end{array}$ & $\begin{array}{l}\text { Thickness } \\
(T, \mathrm{~mm})\end{array}$ & $\begin{array}{c}\text { Spread ratio } \\
\quad(W / T)\end{array}$ & $L^{*}$ & $a^{*}$ & $b^{*}$ & \\
\hline Control & $11.6 \pm 0.3^{\mathrm{c}}$ & $67.8 \pm 0.1^{\mathrm{a}}$ & $10.6 \pm 0.1^{\mathrm{d}}$ & $6.4 \pm 0.1^{\mathrm{a}}$ & $79.1 \pm 0.2^{\mathrm{NS}}$ & $-3.1 \pm 0.1^{\mathrm{a}}$ & $24.9 \pm 0.7^{\mathrm{NS}}$ & $31.7 \pm 1.6^{\mathrm{b}}$ \\
\hline $\begin{array}{l}\text { Mussel } \\
\text { powder 10\% }\end{array}$ & $14.4 \pm 0.6^{\mathrm{b}}$ & $64.3 \pm 0.0^{\mathrm{b}}$ & $12.8 \pm 0.0^{\mathrm{c}}$ & $5.1 \pm 0.1^{\mathrm{b}}$ & $79.1 \pm 0.3$ & $-3.2 \pm 0.3^{\mathrm{a}}$ & $25.7 \pm 0.3$ & $34.1 \pm 0.8^{\mathrm{a}}$ \\
\hline $\begin{array}{l}\text { Mussel } \\
\text { powder 15\% }\end{array}$ & $14.2 \pm 0.4^{\mathrm{b}}$ & $62.3 \pm 0.0^{c}$ & $13.5 \pm 0.1^{\mathrm{b}}$ & $4.6 \pm 0.0^{c}$ & $78.4 \pm 0.4$ & $-4.1 \pm 0.4^{\mathrm{ab}}$ & $26.0 \pm 0.1$ & $35.9 \pm 0.5^{\mathrm{a}}$ \\
\hline $\begin{array}{l}\text { Mussel } \\
\text { powder 20\% }\end{array}$ & $16.5 \pm 0.6^{\mathrm{a}}$ & $60.8 \pm 0.0^{\mathrm{d}}$ & $14.9 \pm 0.2^{\mathrm{a}}$ & $4.1 \pm 0.0^{\mathrm{d}}$ & $78.6 \pm 0.2$ & $-5.0 \pm 0.5^{\mathrm{b}}$ & $25.9 \pm 0.2$ & $35.8 \pm 0.3^{\mathrm{a}}$ \\
\hline $\mathrm{LSD}^{\mathrm{h}}$ & 1.7 & 1.5 & 0.6 & 0.3 & 1.69 & 0.9 & 2.3 & 2.5 \\
\hline
\end{tabular}

${ }^{e}$ Different superscripts (a, b, c, and d) in each column represent the significant difference (Duncan's multiple range test, $p<0.05$ ); values represent mean \pm standard error; not significant (NS) $=$ no significant differences were found $(p \geq 0.05) .{ }^{\mathrm{f}} L^{*}$ is a measure of brightness from $0=$ black to $100=$ white; $a^{*}$ indicates red/green color, with positive $a^{*}$ value indicating redness and negative $a^{*}$ value indicating greenness; $b^{*}$ describes yellowness when the values are positive and blueness when the values are negative. ${ }^{\mathrm{g}}$ Browning index defines brown color. ${ }^{\mathrm{h}} \mathrm{LSD}$, least significant difference.

level of TDF of the fortified biscuits. Foschia et al. [41] reported that the consumption of the cereal dietary fiber might reduce the risk of cardiovascular disease, intestinal regulation, high intestinal glucose level, and forms of colorectal cancer. Basically, increasing the level of the mussel powder from 10 to $20 \%$ resulted in a significant $(p<0.05)$ increase in the level of protein, ash, and TDF, with the $20 \%$ mussel powder biscuit having the highest nutritional values with low carbohydrate levels. Mussel adhesive proteins consisted of rod-like collagenous fibrils, which are of type 1 collagen that may affect the TDF content [6]. Therefore, all biscuits in this study containing TDF of $12.96-28.59 \%$ can be claimed to be "high fiber," according to Regulation (EC) no. 1924/2006, which requires "a claim that a food is high in fiber, and any claim likely to have the same meaning for the consumer may only be made where the product contains at least 6.0\%" [41]. Foschia et al. [41] also reported that a dietary fiber intake among adults is around $18 \mathrm{~g}$ per day. The fiber contents of these biscuits showed that mussel powder and spices could be effectively used to enrich their TDF content without exceeding the recommended daily intake of fiber for consumers.

3.2. Physical Characteristics of the Biscuits. Data on the texture and geometry of the biscuits are presented in Table 3. Biscuits with the addition of mussel powder were significantly $(p<0.05)$ harder than the control biscuits. Therefore, the amount of protein addition seemed to be important to the texture [42]. As the content of mussel powder was increased, the total dietary fiber in the biscuits also increases. It is interesting to note that increasing the mussel powder content also increased the hardness of the biscuits (Table 3). The increase in hardness of the $20 \%$ mussel powder biscuits was significantly higher than that of the control, at $42.4 \%$. The biscuit matrix consisted of starch and sugar in a glassy state and fat globules that were bound to starch and protein in the matrix [21].

The substitution of mussel powder led to a decrease in the width and spread ratio of the biscuits with a significant increase in their thickness. The highest addition of mussel powder in the biscuits $(20 \%)$ had the lowest width and spread ratio and the highest thickness compared to the other three biscuit types. Larger diameter and lower thickness values were observed in the control biscuits. Biscuits with a high spread ratio are more desirable for consumers according to Sarabhai and Prabhasankar [43]. The spread ratios of the fortified biscuits were lower than those in the controls, where spread ratio values of 6.0 have been reported in purple wheat biscuits [9]. Many studies have reported that the width and spread ratio of biscuits decreased with increasing fiber substitution and rice flour incorporation $[44,45]$. The addition of mussel powder at different levels changed the quality of the product in terms of the texture and color parameters [6].

Color parameters are essential for consumers, who either purchase or select to consume food products, including biscuits, on the basis of their color [42]. The color developed during the baking stage can be used to determine the final stage of the baking process. When analyzing the color parameters of the biscuits (Table 3), it was observed that the addition of mussel powder to the biscuits resulted in significant differences $(p<0.05)$ in the redness $\left(a^{*}\right)$ of the biscuit surfaces. This is unsurprising since mussel powder is characterized by a definite green color when compared to the blended flour used. There were no changes observed in the lightness of the biscuits, regardless of the amount of mussel powder added.

Green-lipped mussel powder contained more protein than the substituted wheat-purple rice-blended flour, and the carbohydrates in the biscuit dough came from the plain wheat flour, purple rice flour, and caster sugar. Therefore, the control showed a significantly lower browning index than the other biscuits. This finding is similar to many other studies [21, 45]. The Maillard reaction between the carbohydrates and amino acids was the main factor that changed the color of biscuits in response to the baking temperature and time [42]. Moreover, high browning index values have also been found in bakery products enriched with spices [46].

\subsection{Antioxidant Compounds and Antioxidant Activities.} Purple rice is a rich source of phenolic compounds and anthocyanins, including cyanidin-3-glucoside, which is the predominant anthocyanin in pigmented rice [47]. The levels of bioactive compounds, such as total phenols, anthocyanin, and flavonoid contents, significantly increased $(p<0.05)$ in the mussel powder biscuits (Table 4 ) with the incorporation 
TABLE 4: Bioactive compound contents of fortified biscuits with mussel powder and spices ${ }^{\mathrm{e}}$.

\begin{tabular}{|c|c|c|c|c|c|}
\hline & $\begin{array}{c}\text { Total phenolic content } \\
(\mu \mathrm{g} \cdot \mathrm{GAE} / \mathrm{g} \cdot \mathrm{DW})\end{array}$ & $\begin{array}{c}\text { Anthocyanin } \\
(\mathrm{mg} \cdot \mathrm{Cy}-3-\mathrm{glu} / 100 \mathrm{~g} \cdot \mathrm{DW})\end{array}$ & $\begin{array}{l}\text { Flavonoid contents } \\
(\mu \mathrm{g} \cdot \text { catechin/g.DW })\end{array}$ & $\begin{array}{c}\text { DPPH } \\
(\mu \mathrm{mol} \cdot \text { trolox/g.DW })\end{array}$ & $\begin{array}{c}\text { ABTS } \\
(\mu \mathrm{mol} \cdot \operatorname{trolox} / \mathrm{g} \cdot \mathrm{DW})\end{array}$ \\
\hline Control & $1899.9 \pm 6.8^{\mathrm{d}}$ & $12.4 \pm 0.7^{\mathrm{b}}$ & $761.9 \pm 1.9^{c}$ & $37.4 \pm 0.4^{\mathrm{b}}$ & $10.5 \pm 0.3^{\mathrm{d}}$ \\
\hline Mussel powder $10 \%$ & $2588.7 \pm 1.2^{\mathrm{c}}$ & $18.3 \pm 0.5^{\mathrm{a}}$ & $840.5 \pm 16.9^{c}$ & $38.7 \pm 0.8^{\mathrm{ab}}$ & $53.7 \pm 1.4^{\mathrm{c}}$ \\
\hline Mussel powder $15 \%$ & $2623.6 \pm 5.4^{\mathrm{b}}$ & $19.0 \pm 0.4^{\mathrm{a}}$ & $1341.7 \pm 27.0^{\mathrm{b}}$ & $40.1 \pm 0.4^{\mathrm{ab}}$ & $65.9 \pm 0.6^{\mathrm{b}}$ \\
\hline Mussel powder $20 \%$ & $3081.5 \pm 4.5^{\mathrm{a}}$ & $19.6 \pm 0.5^{\mathrm{a}}$ & $2656.2 \pm 70.5^{\mathrm{a}}$ & $40.6 \pm 0.5^{\mathrm{a}}$ & $73.1 \pm 1.0^{\mathrm{a}}$ \\
\hline $\operatorname{LSD}^{\mathrm{f}}$ & 14.0 & 1.5 & 109.2 & 1.6 & 2.6 \\
\hline
\end{tabular}

GAE, gallic acid equivalent; Cy-3-glu, cyanidin-3-glucoside; DPPH, 2,2-diphenyl-2-picrylhydrazyl radical scavenging activity; ABTS, [2,2'-azinobis(3-ethylbenzothiazoline-6-sulfonic acid)] radical cation scavenging activity. ${ }^{e}$ Different superscripts (a, b, c, and d) in each column represent the significant difference (Duncan's multiple range test, $p<0.05$ ); values represent mean \pm standard error. ${ }^{f}$ LSD, least significant difference.

of increasing levels of powder. A marked difference in total phenolic compounds between the mussel biscuits and the control biscuits was found in this study. In comparison with the control biscuit, the total phenolic content among the fortified biscuits enriched with $10-20 \%$ mussel powder was significantly higher by about $45 \%$. These results could be the effect of the combination of antioxidant compounds derived from mussel powder and spices. Hence, Uhi [11] reported that the ginger and galangal extracts act as an effective antioxidant supplement. The highest values were observed in total phenolic compounds in the $20 \%$ mussel powder biscuits. The total phenolic compounds of the black mussel extract reported by Gorinstein et al. [48] ranged between 3.8 and $6.5 \mathrm{mg} / \mathrm{kg}$ DW using the same extraction process as in this study, while the total phenolic compounds of purple rice ranged between 492 and $2013 \mu \mathrm{g}$ of gallic acid/g DW [48]. Therefore, the increase of total phenolic content among the biscuits enriched with $10-20 \%$ mussel powder was observed due to the total phenolic compounds derived from the defatted mussel powder.

The increase of anthocyanin was significantly higher $(p<0.05)$ in the fortified biscuits prepared with the addition of mussel powder compared to the control biscuits, in which antioxidants from purple rice and spices were similarly incorporated. The level of mussel powder addition had no influence on the anthocyanin contents of the biscuits. In general, anthocyanins are found in high amounts in purple rice [48], but there has been no research on the anthocyanin content in mussel powder. The use of more than $10 \%$ mussel powder biscuit formulation impacted on the flavonoid content. The levels were $248.6 \%$ higher in the $20 \%$ mussel-containing biscuits when compared to the those in the control biscuits containing no mussel powder. Flavonoids can be isolated from the ginger and galangal rhizomes [11], while the major flavonoids in purple rice grains are anthocyanins [23]. Therefore, the fortification of the biscuit ingredients tended to increase the antioxidant compounds from the inclusion of mussel powder, spices, and purple rice flour into the biscuit mix compared to the control biscuits.

Due to the higher levels of bioactive compounds in the mussel biscuits, these biscuits showed $(p<0.05)$ a stronger antioxidant capacity, as measured by the ABTS assays, than the control biscuits (Table 4); but they were relatively less active when the DPPH assay was used. Stoilova et al. [12] stated that ginger extracts have a stronger DPPH activity compared to ABTS. The addition of mussel powder and baking seemed to have had a positive effect on antioxidant activities due to an increase in the Maillard reaction products, which are known for their antioxidant effects [9]. The highest values of polyphenols from the black mussel were extracted with the combination of 50\% methanol, 50\% water, and 1.2 $\mathrm{M} \mathrm{HCl}$ [49], which is a similar extraction used in this study. Many researchers have clearly indicated that ginger and galangal extracts exhibited a strong scavenging effect on DPPH radicals [1, 11-13]. The ABTS scavenging activity of the biscuit extracts may, therefore, be related to the phenolic compounds present.

3.4. Sensory Preference Attributes. Comparisons of the mean liking scores for the sensory attributes of the biscuits, as tested by the four ethnic groups, are presented in Table 5 . The results showed that Pacific Islanders' perceived liking scores were higher than the other three ethnic groups' scores for all attributes tested. An explanation for this finding might be that the preferences towards the food were based on consumers' previous experience [50]. Pacific Islanders traditionally eat diets high in fish and shellfish products $[50,51]$. The familiarity of the consumers with ingredients or types of the product consumed might be the essential factor that affected consumers' attitudes towards these biscuits [51]. Color, texture, and flavor are often considered to be the most important attributes of bakery products, and these also received high scores from the Pacific Islands group. Jantathai et al. [52] also stated that color had a significant influence on the food satisfaction of consumers. Subsequently, Thai consumers gave the mussel biscuits higher liking scores in color, overall appearance, and flavor than consumers from China and Europe, probably resulting from their daily familiarity with purple rice. Biscuits are not usually a preferred choice for Thai consumers; however, the texture of the products was more familiar to them than for the Caucasian consumers. When consumers eat food, they normally choose well-known products rather than less-known ones [52]. The Chinese people living in foreign countries still maintain their Chinese food habits [53]. Therefore, this study can assume that the fortified biscuits were unfamiliar for the Chinese people.

The focus of the analysis of the mussel biscuits was on the color and overall appearance of the biscuits, and the biscuits with $10 \%$ mussel powder did not significantly have different liking scores compared to the control biscuits. This result 
TABLE 5: Average value of sensory liking scores ${ }^{\mathrm{a}}$ of the four different ethnic groups (Thai, Chinese, Caucasian, and Pacific Islander) for the four different fortified biscuits.

\begin{tabular}{|c|c|c|c|c|c|c|c|c|c|c|c|}
\hline \multirow{2}{*}{ Attributes } & & \multicolumn{4}{|c|}{ Ethnic groups } & \multicolumn{3}{|c|}{$p$ value $^{\mathrm{b}}$} & \multirow{2}{*}{$\begin{array}{c}\mathrm{LSD}^{\mathrm{c}} \\
E(5 \%)\end{array}$} & \multirow{2}{*}{$\begin{array}{c}\text { LSD } \\
P(5 \%)\end{array}$} & \multirow{2}{*}{$\begin{array}{c}\text { LSD } \\
E \times P(5 \%)\end{array}$} \\
\hline & & Thai & Chinese & Caucasian & Pacific Islander & $E$ & $P$ & $E \times P$ & & & \\
\hline \multirow{4}{*}{ Color } & Control & 4.5 & 3.9 & 4.9 & 5.8 & \multirow{4}{*}{$<0.01$} & \multirow{4}{*}{$<0.01$} & \multirow{4}{*}{$<0.01$} & \multirow{4}{*}{0.5} & \multirow{4}{*}{0.2} & \multirow{4}{*}{0.2} \\
\hline & Mussel powder $10 \%$ & 5.2 & 4.8 & 5.7 & 5.5 & & & & & & \\
\hline & Mussel powder $15 \%$ & 4.5 & 4.8 & 4.6 & 5.0 & & & & & & \\
\hline & Mussel powder $20 \%$ & 4.7 & 4.6 & 5.2 & 5.0 & & & & & & \\
\hline \multirow{4}{*}{$\begin{array}{l}\text { Overall } \\
\text { appearance }\end{array}$} & Control & 4.8 & 4.5 & 5.1 & 5.9 & \multirow{4}{*}{$<0.01$} & \multirow{4}{*}{0.226} & \multirow{4}{*}{0.01} & \multirow{4}{*}{0.4} & \multirow{4}{*}{0.2} & \multirow{4}{*}{0.2} \\
\hline & Mussel powder $10 \%$ & 5.3 & 4.5 & 5.3 & 5.2 & & & & & & \\
\hline & Mussel powder $15 \%$ & 5.0 & 4.5 & 4.8 & 5.0 & & & & & & \\
\hline & Mussel powder $20 \%$ & 4.8 & 4.9 & 4.8 & 5.4 & & & & & & \\
\hline \multirow{4}{*}{$\begin{array}{l}\text { Touch/ } \\
\text { texture }\end{array}$} & Control & 4.6 & 4.9 & 5.3 & 6.1 & \multirow{4}{*}{$<0.01$} & \multirow{4}{*}{$<0.01$} & \multirow{4}{*}{$<0.01$} & \multirow{4}{*}{0.4} & \multirow{4}{*}{0.2} & \\
\hline & Mussel powder $10 \%$ & 4.5 & 4.9 & 5.4 & 5.3 & & & & & & \\
\hline & Mussel powder $15 \%$ & 4.3 & 4.1 & 5.1 & 5.1 & & & & & & 0.2 \\
\hline & Mussel powder $20 \%$ & 4.3 & 4.6 & 4.4 & 5.1 & & & & & & \\
\hline & Control & 5.3 & 4.6 & 5.3 & 6.1 & & & & & & \\
\hline Touch/ & Mussel powder $10 \%$ & 5.1 & 4.8 & 5.1 & 5.1 & & & & & & \\
\hline oiliness & Mussel powder $15 \%$ & 5.1 & 4.4 & 5.0 & 4.7 & $<0.01$ & $<0.01$ & $<0.01$ & 0.4 & 0.2 & 0.2 \\
\hline & Mussel powder $20 \%$ & 5.2 & 5.0 & 4.4 & 4.9 & & & & & & \\
\hline & Control & 5.2 & 5.3 & 5.8 & 6.2 & & & & & & \\
\hline & Mussel powder $10 \%$ & 4.8 & 4.8 & 4.2 & 5.4 & & & & & & \\
\hline Sweetness & Mussel powder $15 \%$ & 5.2 & 3.8 & 3.0 & 4.9 & $<0.01$ & $<0.01$ & $<0.01$ & 0.5 & 0.2 & 0.2 \\
\hline & Mussel powder $20 \%$ & 4.9 & 3.8 & 3.5 & 5.0 & & & & & & \\
\hline & Control & 3.7 & 4.9 & 5.3 & 6.3 & & & & & & \\
\hline & Mussel powder $10 \%$ & 3.6 & 4.3 & 3.8 & 5.9 & & & & & & \\
\hline Crunchiness & Mussel powder $15 \%$ & 3.7 & 3.8 & 3.4 & 5.1 & $<0.01$ & $<0.01$ & $<0.01$ & 0.4 & 0.2 & 0.2 \\
\hline & Mussel powder $20 \%$ & 3.2 & 4.3 & 3.6 & 5.1 & & & & & & \\
\hline & Control & 5.6 & 5.5 & 5.6 & 6.2 & & & & & & \\
\hline & Mussel powder $10 \%$ & 3.4 & 4.0 & 2.7 & 5.3 & & & & & & \\
\hline Flavor & Mussel powder $15 \%$ & 3.8 & 3.0 & 2.5 & 4.3 & $<0.01$ & $<0.01$ & $<0.01$ & 0.5 & 0.3 & 0.2 \\
\hline & Mussel powder $20 \%$ & 3.4 & 3.4 & 2.2 & 4.1 & & & & & & \\
\hline & Control & 5.3 & 5.1 & 5.8 & 6.1 & & & & & & \\
\hline Overall & Mussel powder $10 \%$ & 4.3 & 3.9 & 3.6 & 5.4 & & & & & & \\
\hline acceptability & Mussel powder $15 \%$ & 4.3 & 3.4 & 2.9 & 5.1 & 0.01 & $<0.01$ & $<0.01$ & 0.4 & 0.2 & 0.2 \\
\hline & Mussel powder $20 \%$ & 3.8 & 3.3 & 2.2 & 4.9 & & & & & & \\
\hline
\end{tabular}

${ }^{a}$ Evaluated on seven-point hedonic scales varying from $1=$ dislike extremely to $7=$ like extremely. ${ }^{b}$ Probability values due to sensory evaluation of the four ethnic groups $(E)$, products $(P)$, and interaction effects $(E \times P)$ were obtained by two-way ANOVA $(p<0.05)$. ${ }^{c}$ LSD, least significant difference.

confirmed that all consumers slightly liked the color, overall acceptance, texture, oiliness, sweetness, and crunchiness of the $10 \%$ mussel powder biscuit. The sensory results showed that more than $10 \%$ mussel powder addition significantly decreased the acceptable scores because of the flavor of the mussel powder. The liking score of overall acceptability of the biscuits had a linear relationship with the addition of mussel powder.

The interaction of biscuits with increasing levels of mussel powder among the four ethnic groups also showed that Pacific Islanders moderately liked the 10\% mussel powder biscuit more than the other ethnic groups, who neither liked nor disliked these biscuits. Caucasians also gave higher scores for the $10 \%$ mussel powder biscuits than the other biscuits for color, overall appearance, texture, and oiliness attributes, when compared to the other ethnic groups. However, Thais preferred the overall appearance and oiliness of the $15 \%$ mussel powder biscuit more than the other biscuits, and they gave a higher score than the consumers from China, Europe, and the Pacific Islands. Vijaykrishnaraj et al. [6] reported that the optimal level of green mussel powder addition in pasta was $5 \%$, while the lowest mussel flavor was found in gluten-free bread fortified with $10 \%$ green mussel protein hydrolysates using quantitative sensory descriptive analysis [6]. The finding of this research clearly showed that the $10 \%$ mussel powder biscuit was accepted by all consumers.

Pearson's correlation between physicochemical properties and sensory evaluation of the biscuits was also undertaken (data not shown). The texture analysis and moisture content of the biscuits were positively correlated to crunchiness and oiliness preference scores from the sensory evaluation $(r=0.58, p<0.01$ and $r=0.71, p<0.05$, resp.). Moreover, the texture liking score appeared to be negatively correlated to the width of the biscuits $(r=-0.41, p<0.05)$. There were no significant relationships between the other characteristics and sensory evaluation tests used in this study. 


\section{Conclusions}

Green-lipped mussel powder clearly provided increased benefits from the antioxidant compounds and antioxidant activities added to the fortified biscuits, without any significant changes to the color of the biscuits. The inclusion of mussel powder from 10 to $20 \%$ in the biscuit mix also affects the antioxidant compounds, particularly total phenolics and flavonoids. However, the addition of mussel powder in wheat-purple rice biscuits significantly $(p<0.05)$ altered their physical characteristics such as the hardness, spread ratio, and browning index resulting from higher fiber contents compared to the control biscuits. Increasing the purple rice and spice contents results in higher nutritional values, also antioxidant properties, and texture of the fortified biscuits compared to the control biscuits. Since protein accounted for the major part of mussel powder, significant differences in flavor between the mussel powder biscuits and the control biscuits were noticeable. This study concluded that mussel powder could be incorporated as the main protein into wheat-purple rice biscuits up to a $10 \%$ level, according to its acceptable product quality as rated by the four different ethnic groups used to evaluate these products.

\section{Conflicts of Interest}

The authors declare that they have no conflicts of interest regarding the publication of this paper.

\section{Acknowledgments}

The author Warinporn Klunklin would like to acknowledge Chiang Mai University, Thailand, and the Postgraduate Research Fund, Lincoln University, Canterbury, NZ, for funding this project. The authors also thank Aroma (NZ) Ltd., Christchurch, for providing defatted green-lipped mussel powder throughout the study and the sensory panelists who were involved with this research work.

\section{References}

[1] C. Caleja, L. Barros, A. L. Antonio, M. B. P. P. Oliveira, and I. C. F. R. Ferreira, "A comparative study between natural and synthetic antioxidants: evaluation of their performance after incorporation into biscuits," Food Chemistry, vol. 216, pp. 342-346, 2017.

[2] J. Park, I. Choi, and Y. Kim, "Cookies formulated from fresh okara using starch, soy flour and hydroxypropyl methylcellulose have high quality and nutritional value," LWT-Food Science and Technology, vol. 63, no. 1, pp. 660-666, 2015.

[3] L. L. Yeh, K. O. Kim, P. Chompreeda, H. Rimkeeree, N. J. N. Yau, and D. S. Lundahl, "Comparison in use of the 9point hedonic scale between Americans, Chinese, Koreans and Thai," Food Quality and Preference, vol. 9, no. 6, pp. 413-419, 1998.

[4] U. Grienke, J. Silke, and D. Tasdemir, "Bioactive compounds from marine mussels and their effects on human health," Food Chemistry, vol. 142, pp. 48-60, 2014.

[5] C. S. Cobb and E. Ernst, "Systematic review of a marine nutriceutical supplement in clinical trials for arthritis: the effectiveness of the New Zealand green-lipped mussel Perna canaliculus," Clinical Rheumatology, vol. 25, no. 3, pp. 275284, 2006.

[6] M. Vijaykrishnaraj, S. B. Kumar, and P. Prabhasankar, "Green mussel (Perna canaliculus) as a marine ingredient to enrich gluten free pasta: product quality, microstructure and biofunctional evaluation," Journal of Food Measurement and Characterization, vol. 9, no. 1, pp. 76-85, 2015.

[7] M. Vijaykrishnaraj, B. S. Roopa, and P. Prabhasankar, "Preparation of gluten free bread enriched with green mussel (Perna canaliculus) protein hydrolysates and characterization of peptides responsible for mussel flavour," Food Chemistry, vol. 211, pp. 715-725, 2016.

[8] H. Zhang, W. S. Xia, Y. S. Xu, Q. X. Jiang, C. X. Wang, and W. J. Wang, "Effects of spray-drying operational parameters on the quality of freshwater mussel powder," Food and Bioproducts Processing, vol. 91, no. 3, pp. 242-248, 2013.

[9] A. Pasqualone, A. M. Bianco, V. M. Paradiso et al., "Production and characterization of functional biscuits obtained from purple wheat," Food Chemistry, vol. 180, pp. 64-70, 2015.

[10] R. Yawadio, S. Tanimori, and N. Morita, "Identification of phenolic compounds isolated from pigmented rices and their aldose reductase inhibitory activities," Food Chemistry, vol. 101, no. 4, pp. 1616-1625, 2007.

[11] S. R. Uhl, Handbook of Spices, Seasonings, and Flavorings, Technomic Publishing Company, Inc., Lancaster, PA, USA, 2000.

[12] I. Stoilova, A. Krastanov, A. Stoyanova, P. Denev, and S. Gargova, "Antioxidant activity of a ginger extract (Zingiber officinale)," Food Chemistry, vol. 102, no. 3, pp. 764-770, 2007.

[13] C. Buaniaw, S. Siripongvutikorn, and C. Thongraung, "Effectiveness of ethanolic galangal extract (Alpinia galanga Linn.) on inhibition of lipid oxidation in fish muscle systems," International Journal of Food Science and Technology, vol. 45, no. 11, pp. 2373-2378, 2010.

[14] D. Vitali, I. V. Dragojević, and B. Šebečić, "Effects of incorporation of integral raw materials and dietary fibre on the selected nutritional and functional properties of biscuits," Food Chemistry, vol. 114, no. 4, pp. 1462-1469, 2009.

[15] Association of Official Agricultural Chemistry, Official Methods of Analysis International, AOAC, Gaithersburg, MD, USA, 17th edition, 2002.

[16] M. O. Reed, Y. Ai, J. L. Leutcher, and J. Jane, "Effects of cooking methods and starch structures on starch hydrolysis rates of rice," Journal of Food Science, vol. 78, no. 7, pp. H1076-H1081, 2013.

[17] W. R. Akeson and M. A. Stahmann, "A pepsin pancreatin digest index of protein quality evaluation," Journal of $\mathrm{Nu}$ trition, vol. 83, no. 3, pp. 257-261, 1964.

[18] J. A. Monro, S. Mishra, and B. Venn, "Baselines representing blood glucose clearance improve in vitro prediction of the glycemic impact of customarily consumed food qualities," British Journal of Nutrition, vol. 103, no. 2, pp. 295-305, 2010.

[19] American Association of Cereal Chemists, Baking Quality of Cookie Flour-Micro Method, Approved Methods 10-50.05, AACC, St. Paul, MN, USA, 1967.

[20] American Association of Cereal Chemists, Baking Quality of Cookie Flour-Micro Method, Approved Method 10-50D, AACC, St. Paul, MN, USA, 2000.

[21] N. Sozer, L. Cicerelli, R. L. Heiniö, and K. Poutanen, "Effect of wheat bran addition on in vitro starch digestibility, physicomechanical and sensory properties of biscuits," Journal of Cereal Science, vol. 60, no. 1, pp. 105-113, 2014.

[22] A. Ruangchakpet and T. Sajjaanantakul, "Effect of browning on total phenolic, flavonoid content and antioxidant activity 
in Indian gooseberry (Phyllanthus emblica Linn.)," Kasetsart Journal (Natural Science), vol. 41, pp. 331-337, 2007.

[23] S. Jang and Z. Xu, "Lipophilic and hydrophilic antioxidants and their antioxidant activities in purple rice bran," Journal of Agricultural and Food Chemistry, vol. 57, no. 3, pp. 858-862, 2009.

[24] I. Kaneda, F. Kubo, and H. Sakurai, "Antioxidative compounds in the extracts of black rice bran," Journal of Health Sciences, vol. 52, no. 5, pp. 495-511, 2006.

[25] J. Zhishen, T. Mengcheng, and W. Jianming, "The determination of flavonoid contents in mulberry and their scavenging effects on superoxide radicals," Food Chemistry, vol. 64, no. 4, pp. 555-559, 1999.

[26] F. S. Hosseinian, W. Li, and T. Beta, "Measurement of anthocyanins and other phytochemicals in purple wheat," Food Chemistry, vol. 109, no. 4, pp. 916-924, 2008.

[27] P. Mahakunakorn, M. Tohda, Y. Murakami, K. Matsumoto, and $\mathrm{H}$. Watanabe, "Antioxidant and free radical-scavenging activity of chitosan and its related constituents," Biological and Pharmaceutical Bulletin, vol. 27, no. 1, pp. 38-46, 2004.

[28] R. Re, N. Pellegrini, A. Proteggente, A. Pannala, M. Yang, and C. Rice-Evans, "Antioxidant activity applying an improved ABTS radical cation decolourization assay," Free Radical Biology and Medicine, vol. 26, no. 9-10, pp. 1231-1237, 1999.

[29] A. Abdullah and T. C. Cheng, "Optimization of reduced calorie tropical mixed fruits jam," Food Quality and Preference, vol. 12, no. 1, pp. 63-68, 2001.

[30] O. A. Kure, E. J. Bahago, and E. A. Daniel, "Studies on the proximate composition and effect of particle size on acceptability of biscuit produced from blends of soyabeans and plantain flours," Namida Tech-Scope Journal, vol. 3, pp. 17-21, 1998.

[31] S. P. Cauvain and L. S. Young, Bakery Food Manufacture and Quality: Water Control and Effects, Blackwell Publishing, Oxford, UK, 2nd edition, 2009.

[32] A. R. Oliveira, A. V. Sykes, I. Hachero-Cruzado, U. M. Azeiteiro, and E. Esteves, "A sensory and nutritional comparison of mussels (Mytilus sp.) produced in NW Iberia and in the Armona offshore production area (Algarve, Portugal)," Food Chemistry, vol. 168, pp. 520-528, 2015.

[33] W. J. Boobier, J. S. Baker, and B. Davies, "Development of a healthy biscuit: an alternative approach to biscuit manufacture," Nutrition Journal, vol. 5, no. 1, pp. 1-7, 2006.

[34] E. S. Abdel-Aal, "Effects of baking on protein digestibility of organic spelt products determined by two in vitro digestion methods," LWT-Food Science and Technology, vol. 41, no. 7, pp. 1282-1288, 2008.

[35] D. Sumczynski, E. Kotásková, H. Družbíková, and J. Mlček, "Determination of contents and antioxidant activity of free and bound phenolics compounds and in vitro digestibility of commercial black and red rice (Oryza sativa L.) varieties," Food Chemistry, vol. 211, pp. 339-346, 2016.

[36] A. G. Lima, M. T. Barum, R. P. Ramirez, S. F. Fonseca, S. Pieniz, and K. L. Rodrigues, "Acceptability, nutritional composition, and protein digestibility of food produced with black rice," Journal of Culinary Science and Technology, vol. 16, no. 1, pp. 30-39, 2017.

[37] J. V. Nørgaard, J. K. Petersenb, D. B. Tørring, H. Jørgensena, and H. N. Lærke, "Chemical composition and standardized ileal digestibility of protein and amino acids from blue mussel, starfish, and fish silage in pigs," Animal Feed Science and Technology, vol. 205, pp. 90-97, 2015.

[38] S. H. Ng, S. D. Robert, W. A. N. W. Ahmad, and W. R. W. Ishak, "Incorporation of dietary fibre-rich oyster mushroom (Pleurotus sajor-caju) powder improves postprandial glycaemic response by interfering with starch granule structure and starch digestibility of biscuit," Food Chemistry, vol. 227, pp. 358-368, 2017.

[39] L. U. Thompson and J. H. Yoon, "Starch digestibility as affected by polyphenols and phytic acid," Journal of Food Science, vol. 49, no. 4, pp. 1228-1229, 1984.

[40] R. Sompong, S. Siebenhandl-Ehn, G. Linsberger-Martin, and E. Berghofer, "Physicochemical and antioxidative properties of red and black rice varieties from Thailand, China and Sri Lanka," Food Chemistry, vol. 124, no. 1, pp. 132-140, 2011.

[41] M. Foschia, D. Peressini, A. Sensidoni, and C. S. Brennan, "The effects of dietary fibre addition on the quality of common cereal products," Journal of Cereal Science, vol. 58, no. 2, pp. 216-227, 2013.

[42] M. Krystyjan, D. Gumul, R. Ziobro, and A. Korus, "The fortification of biscuits with bee pollen and its effect on physicochemical and antioxidant properties in biscuits," LWT-Food Science and Technology, vol. 63, no. 1, pp. 640-646, 2015.

[43] S. Sarabhai and P. Prabhasankar, "Influence of whey protein concentrate and potato starch on rheological properties and baking performance of Indian water chestnut flour based gluten free cookie dough," LWT-Food Science and Technology, vol. 63, no. 2, pp. 1301-1308, 2015.

[44] M. L. Sudha, R. Vetrimani, and K. Leelavathi, "Influence of fibre from different cereals on the rheological characteristics of wheat flour dough and on biscuit quality," Food Chemistry, vol. 100, no. 4, pp. 1365-1370, 2007.

[45] P. Sharma and H. S. Gujral, "Cookie making behaviour of wheat-barley flour blends and effects on antioxidant properties," LWT-Food Science and Technology, vol. 55, no. 1, pp. 301-307, 2014

[46] M. Przygodzka, H. ZieliNski, Z. Ciesarová, K. Kukurová, and G. Lamparski, "Study on sensory quality, antioxidant properties, and Maillard reaction products formation in ryebuckwheat cakes enhanced with selected spices," Journal of Chemistry, vol. 2015, Article ID 418639, 9 pages, 2015.

[47] R. Chatthongpisut, S. J. Schwartz, and J. Yongsawatdigul, "Antioxidant activities and antiproliferative activity of Thai purple rice cooked by various methods on human colon cancer cells," Food Chemistry, vol. 188, pp. 99-105, 2015.

[48] S. Gorinstein, S. Moncheva, E. Katrich et al., "Antioxidants in the black mussel (Mytilus galloprovincialis) as an indicator of black sea coastal pollution," Marine Pollution Bulletin, vol. 46, no. 10, pp. 1317-1325, 2003.

[49] S. Moncheva, S. Trakhtenberg, E. Katrich et al., "Total antioxidant capacity in the black mussel (Mytilus galloprovincialis) from Black Sea coasts," Estuarine, Coastal and Shelf Science, vol. 59, no. 3, pp. 475-484, 2004.

[50] K. E. Charlton, J. Russell, E. Gorman et al., "Fish, food security and health in Pacific Island countries and territories: a systematic literature review," BMC Public Health, vol. 16, no. 1, pp. 285-301, 2016.

[51] C. Polet and H. Bocherens, "New insights into the marine contribution to ancient Easter Islanders' diet," Journal of Archaeological Science, vol. 6, pp. 709-719, 2016.

[52] S. Jantathai, M. Sungsri-in, A. Mukprasirt, and M. Duerrschmid, "Sensory expectations and perceptions of Austrian and Thai consumers: a case study with six colored Thai desserts," Food Research International, vol. 64, pp. 65-73, 2014.

[53] G. Ma, "Food, eating behavior, and culture in Chinese society," Journal of Ethnic Foods, vol. 2, no. 4, pp. 195-199, 2015. 


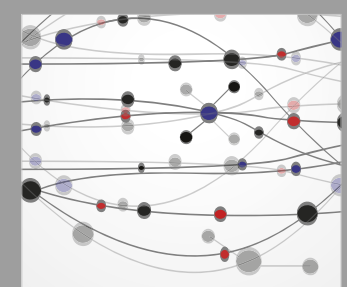

The Scientific World Journal
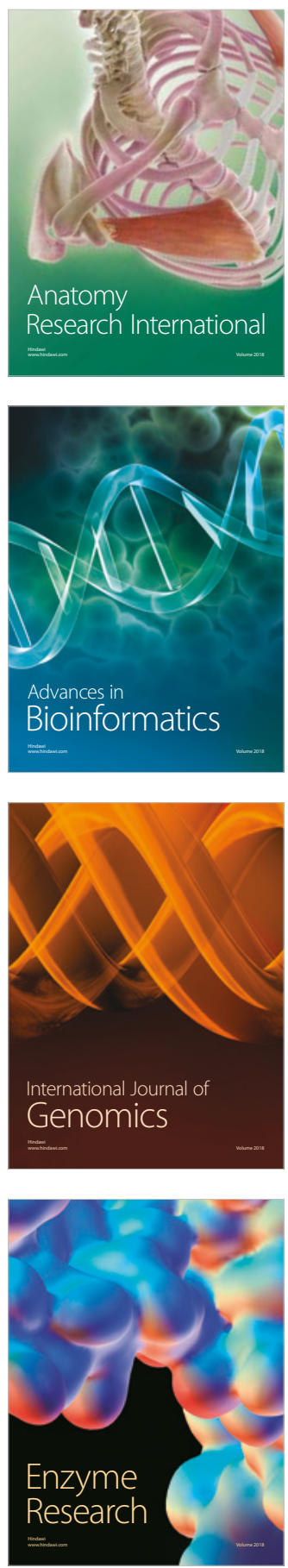
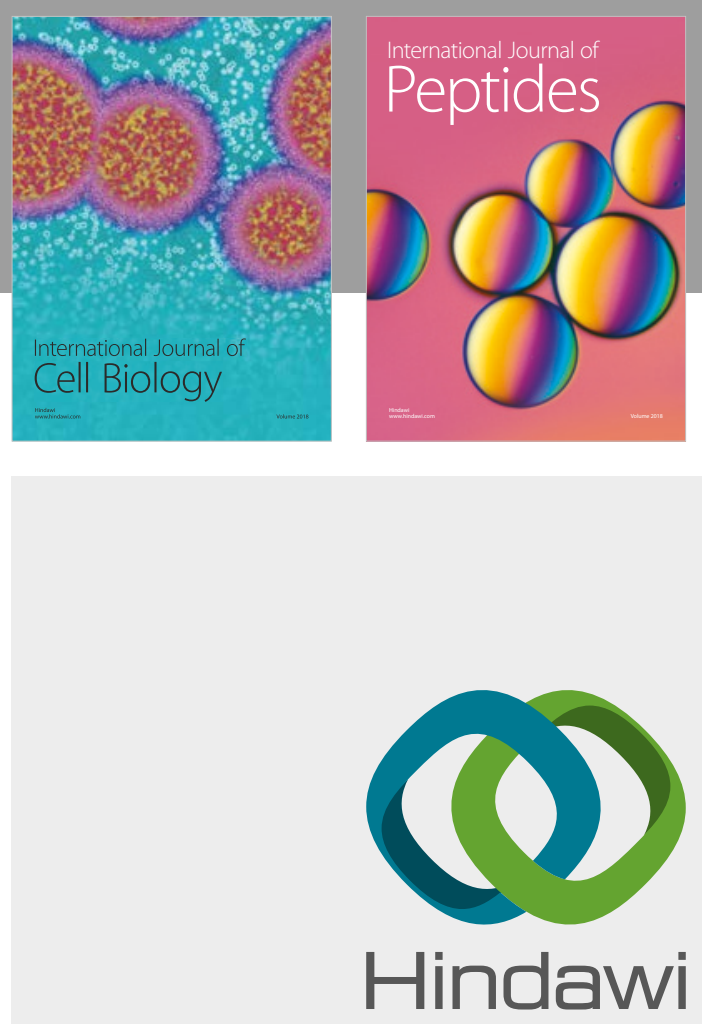

Submit your manuscripts at

www.hindawi.com
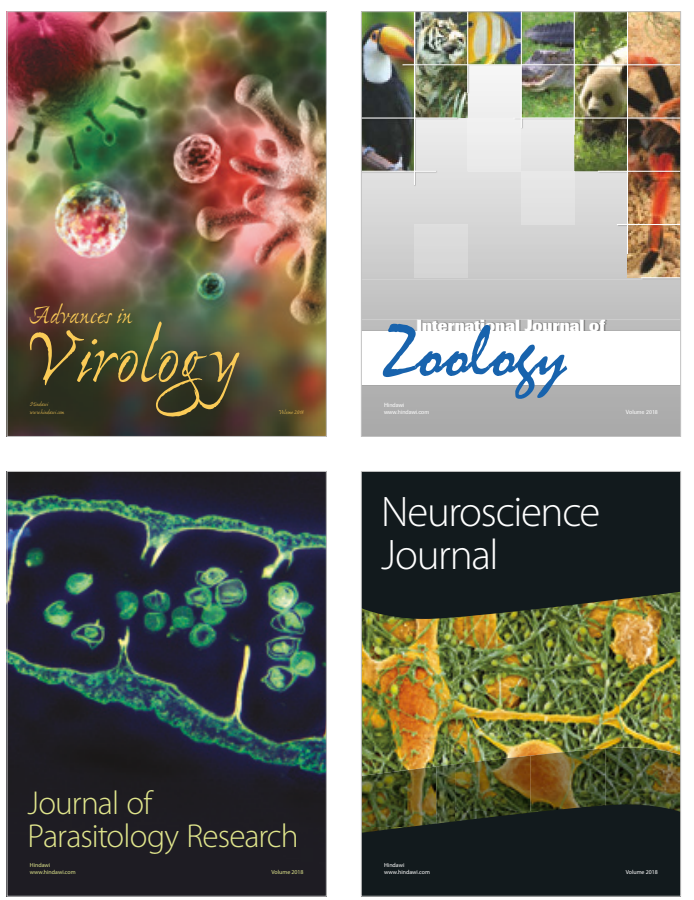
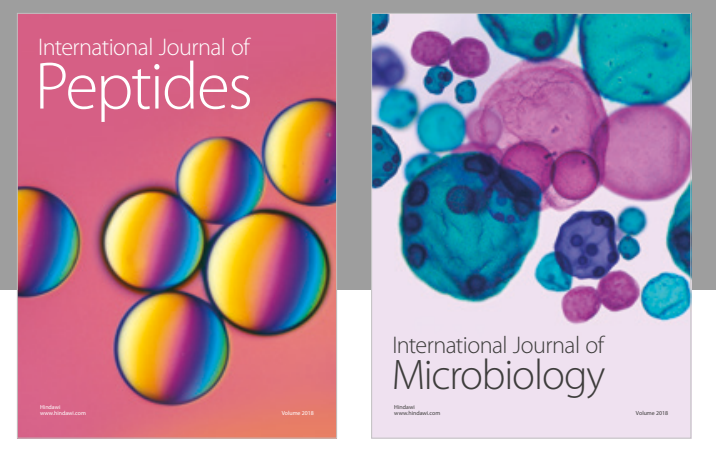

nternational Journal of Microbiology
Journal of
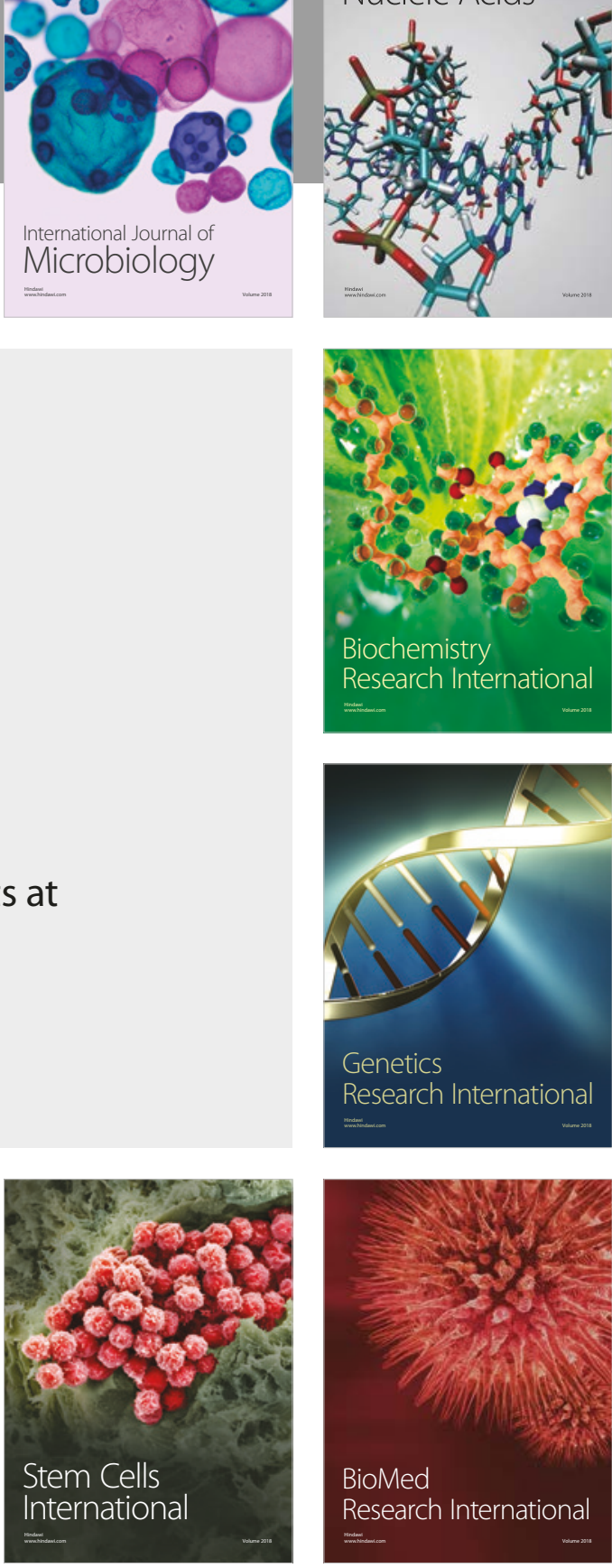
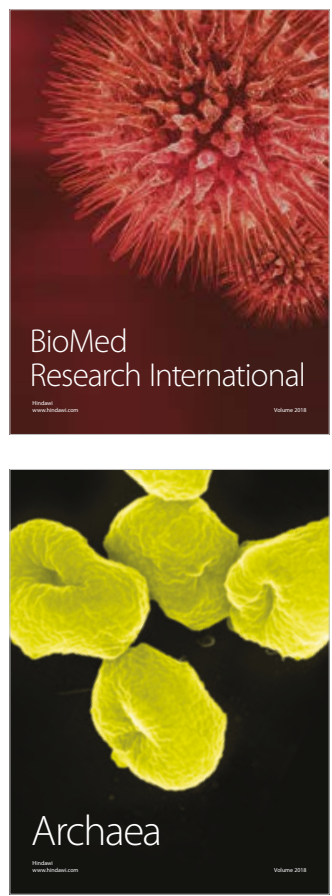